\title{
COMPARATIVE STUDY OF BS 8110 AND EUROCODE 2 IN STRUCTURAL DESIGN AND ANALYSIS
}

\author{
C. U. Nwoji ${ }^{1}$ and A. I. Ugwu ${ }^{2, *}$ \\ 1,2 DePartment of Civil EngineERING, UNIVERSity of Nigeria, NSUKKA, ENUGU STATE, NIGERIA. \\ Email addresses:1 cunwoji@yahoo.com, ${ }^{2}$ ugwualbert@gmail.com
}

\begin{abstract}
This work was undertaken to compare the use of BS 8110 and Eurocode 2 in the design of structures and focused on outlining the relative gains and/or shortcomings of Eurocode 2 and BS 8110 under certain criteria which are loading, analysis, ease of use and technological advancement. To accomplish this, the analysis and design of the main structural elements in reinforced concrete building was undertaken using the two codes. A modest medium rise building was loaded using the two code and analyzed. Analysis was done using CSI start tedds to obtain the shear force and bending moment envelopes. For the beam, it was found that Eurocode 2 gave higher internal supports moments. For the case of maximum span moments and shear force values, the Euroode 2 values lagged behind. Column load and moments values were generally lower for Euroode 2. In summary, the comparative benefits of using Euroode 2 are that it is logical and organized, less restrictive and more extensive than the BS 8110. The new Eurocodes are claimed to be the most technically advanced code in the world and therefore should be adopted by Nigerian engineers.
\end{abstract}

Keywords: Codes, design, moments, shears, BS 8110, Eurocode.

\section{INTRODUCTION}

Reinforced concrete structure is a common composite material used in construction. Reinforced concrete is a combination of two dissimilar but complimentary materials, namely concrete and steel [1]. Concrete also known as artificial stone is produced by mixing sand, cement, aggregates, and water [2]. Fresh concrete can be customized into any shape depending on the mound in which it is cast into. Steel, on the other hand, is a metal alloy that is composed principally of iron and carbon [3]. Concrete and steel combined as reinforced concrete (RC) is widely used in construction and other applications [4]. The reinforcement is usually, though not necessarily, steel reinforcing bars and is usually embedded passively in the concrete before the concrete sets [2].

Design methods are formulated based on philosophies, leading to design codes attendant to a particular design method. The use of different design methods and codes will definitely bring about different results in structural analysis and design leading to variability in behaviour, costs and durability of structures. It is, always, the duty of the structural engineer to provide designs that would lead to optimum performance and economy by employing the most efficient design method in accordance with a relevant design code available, in order to satisfy the client's requirements. Structural design has gone through various stages, each stage on a design philosophy which tries to produce a structure that will be reversibly safe. It is based on creative ability, imagination and experience, which are all tied to sound scientific principles. It is, thus, open-ended.

A new code Eurocode is now in use in the European Union (EU) countries for structural design. This code is meant to unify design philosophies and make civil engineers productive across all of Europe. Nigeria as a commonwealth country and without a code of her own has since been using the design codes of the United Kingdom. This work investigates and compares the use of Eurocode 2 and BS 8110 in the design of reinforced concrete structures to see if Eurocode 2 would be adopted as the official design code for reinforced concrete structures in Nigeria in place of BS 8110, which has been the official design code for the country for decades. The study will establish the differences between the two codes in terms of loading analysis, ease of use and technological advancement, by considering the loading and analysis of beams, slabs, columns and foundation footings, which are representative structural elements for the study. 


\section{LITERATURE REVIEW}

\section{$2.1 \mathrm{BS} 8110$}

BS 8110 is a British Standard for the design and construction of reinforced and prestressed concrete structures. It is based on limit state design principles. Although used for most civil engineering and building structures, bridges and water-retaining structures are covered by separate standards (BS 5400 and BS 8007). In 2010, BS 8110 was superseded by EN 1992 (Eurocode 2) although parts of the standard have been retained in the National Annex of the Eurocode [6].

BS 8110 was first published in 1985 and later revised in the year 1997. The 1997 edition of BS 8110 supersedes the earlier edition and is made up of the following three parts [5]:

i. BS 8110-1:1997 (Structural Use of Concrete-Code of Practice for Design and Construction): It is a revision of BS 8110-1:1985 which is withdrawn. BS 81101:1997 incorporates all published amendments made to BS 8110-1:1985.

ii. BS 8110-2:1997 (Structural Use of Concrete-Code of Practice for Special Circumstances):

iii. BS 8110-3:1997 (Structural Use of Concrete-Design Charts for Singly Reinforced Beams and charts for Reinforced Concrete Columns.

\subsection{Eurocode 2 (EC 2)}

Eurocode 2 and EC2 are both abbreviations for BS EN 1992 (Eurocode 2): Design of concrete structures [6]. When referring to Eurocode 2, most people mean BS EN 1992-1-1. This code was the result of the Commission of the European Community's decision to eliminate technical obstacles to trade and harmonize technical specifications. The Structural Eurocode programme comprises standards generally consisting of a number of Parts [6].

\subsection{BS 8110 and Eurocode 2 in the Analysis and Design of Concrete Structures.}

In the last three decades an alternative set of codes to replace the British and other European national standards were developed termed the Eurocodes (ECs). These comprehensive set of harmonized Eurocodes for the structural and geotechnical design of buildings and civil engineering works were first introduced as Euronorme Voluntaire (ENV) standards, intended for use in conjunction with national application documents (NADs) as an alternative to national codes such as BS8110-1997 for a limited number of years [7].

One of the major advantages of this unification is that designs will be easily understood and ideas communicated easily between countries that use the Eurocodes for thei designs. Also, engineers would be able to work in any country using the Eurocodes and so gives the engineer better opportunities and easy adjustments.

\section{RESEARCH METHODOLOGY}

\subsection{Design method}

The method recommended in the codes (both BS 8110 and Eurocode 2) is that of limit state design. Account should be taken of accepted theory, experiment and experience and the need to design for durability. The analysis steps for design are given separately for each structural element designed. The step by step procedure for the analysis if given in 3.2 below. Design is not covered in this research.

\subsection{Analysis of structure}

The primary objective of structural analysis is to obtain a set of internal forces and moments throughout the structure that are in equilibrium with the design loads for the required loading combinations [9]. The methodology for analysis of the different structural elements are summarized as:

\subsubsection{Slabs}

The dead slab which include self-weight (weight of concrete), partition, services, finishes and added dead load (masonry walls, etc.) a computed in $\mathrm{kN} / \mathrm{m}^{2}$. The appropriate live load based on the use of the building is selected from the appropriate codes. Afterwards the total slab lad is calculated as given in the codes (refer to Table 1). Then slab is analyzed either by elastic analysis or by using moment coefficients given in the relevant tables.

\subsubsection{Beams}

The load from adjoining slabs are transferred to the beam using the method given in table 63 of Reinforced concrete designers manual by Reynolds et al. the beam self-weight and wall load (if applicable) are added. The beam is then analyzed for different load cases as prescribed by the code to obtain the bending moment and shear force envelopes. The computer software used for the analysis is CSC start Tedds. Under design ultimate loads, any implied redistribution of forces and moments should be compatible with the ductility of the members concerned.

\subsubsection{Columns}

The load take-down (N) and moment (M) are evaluated for the most onerous load combination. The combination of axial load and moment is used for the study.

\subsubsection{Foundation}

The load take-down to the footing supporting the column is calculated both ultimate and service load. The service 
load is used to size the pad plan section while the ultimate load is use the section design.

\subsection{Model}

The model adopted for this study is a modest medium rise building; the Faculty of Engineering building, University of Nigeria Nsukka. The building is a two storey building consisting of 2 suspended floors and one $\mathrm{RC}$ roof slab. The second floor serve office/classroom purpose while the 1st floor serve office/hall (drawing hall) purpose. The building is about $10 \mathrm{~m}$ high having an approximate plan dimension of $60 \mathrm{~m} \times 20 \mathrm{~m}$. The General Arrangement (G.A) drawing is shown in Fig 1 and elevation is shown Fig 2.

Representative elements for the loading and analysis are taken from the structure (G. A. shown in Fig 1). A slab (slap panel P3), a beam (Beam 2B), a column (column C1), and a footing (column C1 footing) were loaded, analyzed and informed design comments made based on the analysis results. Table 1 provides some information on the loading and analysis of structural members for both BS 8110 and EC 2 .

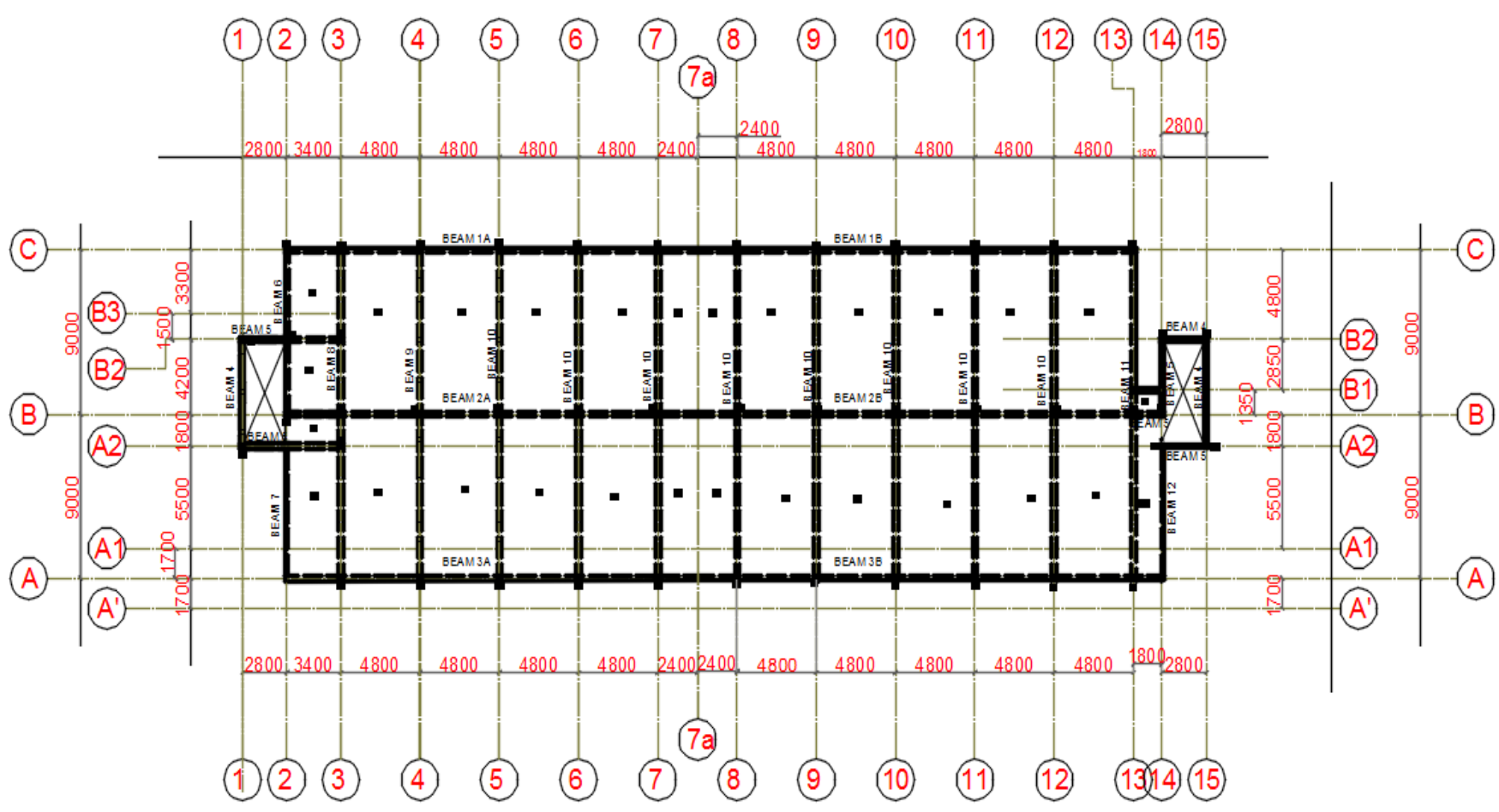

SECOND FLOOR GENERAL ARRANGEMENT DRAWING

Figure1: Representative floor plan

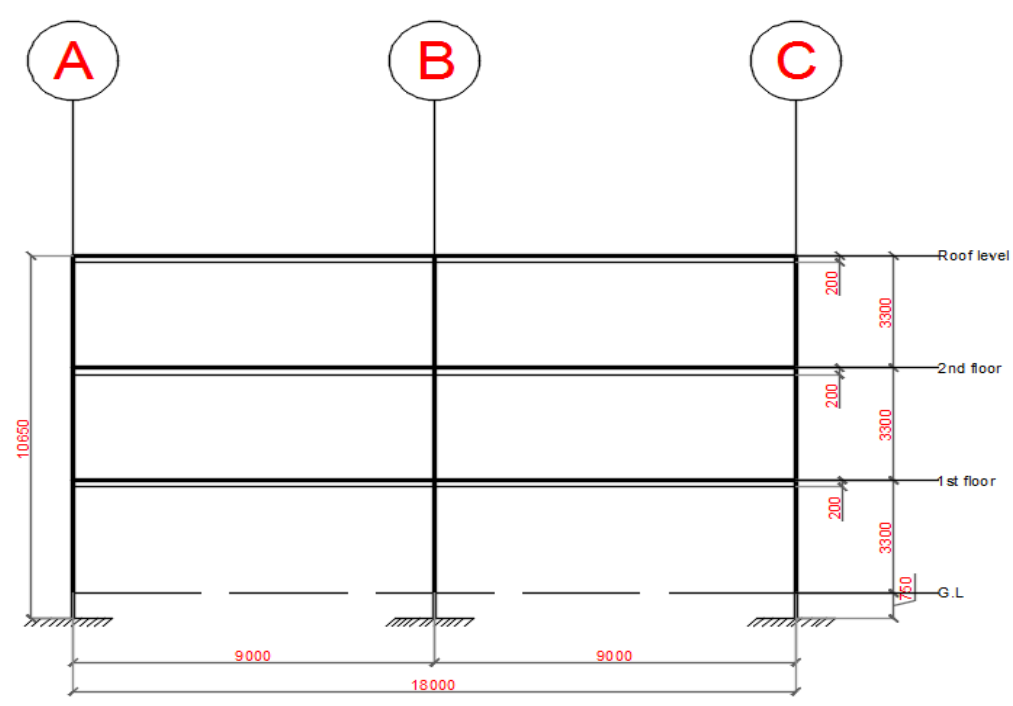

Figure 2: Frame elevation 
Table 1: Limit state loading information for BS 8110 and Eurocode 2 codes.

\begin{tabular}{lcc}
\hline \multicolumn{1}{c}{ Span } & BS 8110 & EC 2 \\
\hline Loaded spans & $1.4 \mathrm{DL}+1.6 \mathrm{IL}$ & $1.35 \mathrm{DL}+1.5 \mathrm{IL}$ \\
Unloaded spans & $1.0 \mathrm{DL}$ & $1.35 \mathrm{DL}$ \\
\hline
\end{tabular}

BS 8110 recommends a loading pattern as follows

i- all spans ultimate loading

ii- alternate span ultimate loading

iii- reverse of ii

EC 2 recommends a loading pattern as follows

i- all spans ultimate loading

ii- adjacent span ultimate loading

iii- alternate span ultimate loading

With respect to load estimation, BS 8110 recommends unit weight of concrete $24 \mathrm{kN} / \mathrm{m}^{3}$ while EC 2 recommends unit weight of concrete $25 \mathrm{kN} / \mathrm{m}^{3}$

\section{ANALYSIS OF STRUCTURAL ELEMENTS}

\subsection{Slab loading and analysis}

The results of loading and analysis for slab are presented hereunder.

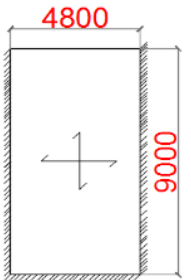

a

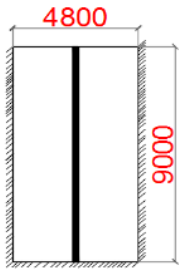

$\mathrm{b}$

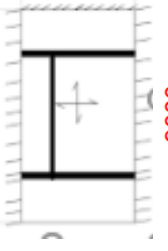

$\mathrm{C}$

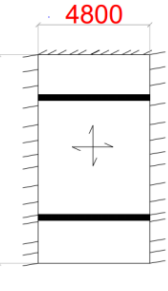

d
Figure 3: sketch of slab panel

$k=\frac{l_{y}}{l_{x}}=\frac{9000}{4800}=1.875<2$

(Two-way spanning slab)

where Ly $=$ Longer span length and Lx = Shorter span length

Thickness of slab $=200 \mathrm{~mm}$

The service dead load estimation for all the slabs are given in details below;

For slab panels 1 and 3 (Fig 3a)

Slab self-weight $=0.2 \times 24=4.8 \mathrm{kN} / \mathrm{m}^{2}$

Finishes $\quad=1.5 \mathrm{kN} / \mathrm{m}^{2}$

Light wt. partitions $\quad=\underline{1.0 \mathrm{kN} / \mathrm{m}^{2}}$

Characteristic dead load $=7.3 \mathrm{kN} / \mathrm{m}^{2}$

Characteristic imposed load $=3.0 \mathrm{kN} / \mathrm{m}^{2}$

For slab panel 2 (Fig 3c)

Equivalent distributed load due to wall,

$\mathrm{W}_{\mathrm{e}}=\mathrm{W}_{\mathrm{e} 1}+\mathrm{W}_{\mathrm{e} 2}+\mathrm{W}_{\mathrm{e} 3}$

Full brick wall parallel to span slab, $\mathrm{W}_{\mathrm{e}}=\mathrm{W}_{\mathrm{p}} / \mathrm{e}$

where $e=h_{p}+0.61 ; h_{p}=$ width of wall, $l=$ slab span

$\mathrm{e}=0.23+(0.6 \times 5)=3.23 \mathrm{~m}$

$\mathrm{W}_{\mathrm{p}}=3.54 \times 3.3 \times 0.3=9.16 \mathrm{kN} / \mathrm{m}$
$\mathrm{W}_{\mathrm{e} 1}=9.16 / 3.23=2.84 \mathrm{kN} / \mathrm{m}^{2}$

Block $/$ wood $=\left(\begin{array}{lllll}3.54 & \times & 0.9 & \times & 0.85\end{array}\right)+(1 \times 2.4)=$ $5.04 \mathrm{kN} / \mathrm{m}$

$\mathrm{W}_{\mathrm{e} 2}=5.04 / 3.23=1.56 \mathrm{kN} / \mathrm{m}^{2}$

Wall perpendicular to span of slab,

$3 \mathrm{~W}_{\mathrm{p}} / 2 \mathrm{l}=(3 \times 9.16) /(2 \times 4.8)=2.19 \mathrm{kN} / \mathrm{m}^{2}$

$\mathrm{W}_{\mathrm{e}}=2.84+1.56+2.19=6.59 \mathrm{kN} / \mathrm{m}^{2}$

Characteristic dead load, $\mathrm{G}_{\mathrm{k}}=7.3+6.59=13.9 \mathrm{kN} / \mathrm{m}^{2}$

Characteristic imposed load $=3.0 \mathrm{kN} / \mathrm{m}^{2}$

For slab panel 4 (Fig 3d)

Characteristic dead load, $\mathrm{G}_{\mathrm{k}}=7.3+2.84+1.56=$ $11.7 \mathrm{kN} / \mathrm{m}^{2}$

$$
\text { imposed " } \mathrm{Q}_{\mathrm{k}}=3.0 \mathrm{kN} / \mathrm{m}^{2}
$$

For slab panel 8 (Fig 3b)

Load on slab due to wall $=3 \mathrm{~W}_{\mathrm{p}} / 2 \mathrm{l}=(3 \times 3.47 \times 3.3) /(2$ $\mathrm{x} 4.8)=3.578 \mathrm{kN} / \mathrm{m}^{2}$

Characteristic dead load, $\mathrm{G}_{\mathrm{k}}=7.3+3.578=10.9 \mathrm{kN} / \mathrm{m}^{2}$

For the slab analysis, only slab panel 3 was done.

Loading (Bs 8110)

Slab design load, $\mathrm{n}=\left(1.4 \mathrm{G}_{\mathrm{k}}\right)+\left(1.6 \mathrm{Q}_{\mathrm{k}}\right)=(1.4 \times 7.3)+$ $(1.6 \times 3)=15.1 \mathrm{kN} / \mathrm{m}^{2}$

Bending moment coefficients $(\mathrm{k}=1.875)$ :

From Table 3.14 of BS 8110-1; 1997 [5].

$M_{s x}=\beta_{s x} n l_{x}$

$M_{s y}=\beta_{s y} n l_{x}$

where $\beta_{s x}$ and $\quad \beta_{s y}$ are moment

coefficients from Table 3.14 BS 8110-1; 1997 [5].and $n$ is the total ultimate load per unit area of slab.

$\beta_{s x}^{\prime}=0.065, \beta_{s y}^{\prime}=0.037, \beta_{s x}=0.049, \quad \beta_{s y}=0.028$

Table 3.14 of BS 8110-1; 1997 [5].

$\mathrm{M}_{\mathrm{sx}}=0.065 \times 15 \times 4.8^{2}=22.5 \mathrm{kNm}$,

$\mathrm{M}_{\text {sy }}^{\prime}=0.037 \times 15 \times 4.8^{2}=12.8 \mathrm{kNm}$

$\mathrm{M}_{\mathrm{sx}}=0.049 \times 15 \times 4.8^{2}=16.9 \mathrm{kNm}$,

$\mathrm{M}_{\text {sy }}=0.028 \times 15 \times 4.8^{2}=9.7 \mathrm{kNm}$

From Table 3.15 of BS 8110-1; 1997 [5].

$\mathrm{V}_{\text {max }}=0.53 \mathrm{nl}_{\mathrm{x}}=0.53 \times 15.1 \times 4.8=38.4 \mathrm{kN}$

Loading (EC 2)

Slab design load,

$$
\begin{array}{r}
\mathrm{n}=1.35 \mathrm{G}_{\mathrm{k}}+1.5 \mathrm{Q}_{\mathrm{k}} \\
=(1.35 \times 7.5)+(1.5 \times 3)=14.4 \mathrm{kN} / \mathrm{m}^{2}
\end{array}
$$

Ultimate BM's:

Bending moment coefficients and moments $(\mathrm{k}=1.875)$ :

$\beta_{s x}^{\prime}=0.065, \beta_{s y}^{\prime}=0.037, \beta_{s x}=0.049, \beta_{s y}=0.028$

$\mathrm{M}_{\mathrm{sx}}=0.065 \times 14.6 \times 4.8^{2}=21.8 \mathrm{kNm}$,

$\mathrm{M}_{\text {sy }}^{\prime}=0.037 \times 14.6 \times 4.8^{2}=12.4 \mathrm{kNm}$

$\mathrm{M}_{\mathrm{sx}}=0.049 \times 14.6 \times 4.8^{2}=16.5 \mathrm{kNm}$,

$\mathrm{M}_{\mathrm{sy}}=0.028 \times 14.6 \times 4.8^{2}=9.4 \mathrm{kNm}$

$\mathrm{V}_{\text {max }}=0.53 \mathrm{nl}_{\mathrm{x}}=0.53 \times 14.6 \times 4.8=37.1 \mathrm{kN}$

From the above analysis, it was seen that the dead load for EC design was higher than that of BS 8110 due to a 
higher unit weight of concrete used in the estimation of the load. However, the design load for EC 2 is lower than that of BS8110. This is due to the fact that partial factors of safety for BS 8110 is higher than that of EC 2 for both dead load and imposed load.

\subsection{Beam loading and analysis}

Loading summary for each span of the beam for ultimate limit state and serviceability limit state is summarized in Tables 2 and 3 .

\section{BEAM 2B Sketch}

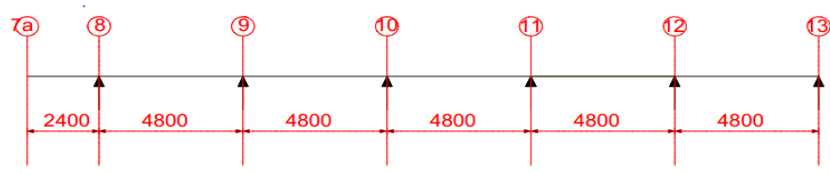

Fig 4: sketch of Beam 2B: GL B (7a-14)
Based on loading formula given by Reynolds and Steedman [10].

Load from slab to connected main beam $=R_{3}=0.25 \mathrm{nl}_{\mathrm{x}}$ $=0.25 \times 4.8 \mathrm{n}=1.2 \mathrm{n}$

Table 2: Beam 2B Load Case (BS 8110)

\begin{tabular}{llllrlr}
\hline SPAN & \multicolumn{2}{c}{ CASE 1 } & \multicolumn{2}{c}{ CASE 2 } & \multicolumn{2}{c}{ CASE 3 } \\
\hline & DL & IL & DL & \multicolumn{1}{c}{ IL } & \multicolumn{1}{l}{ DL } & \multicolumn{1}{c}{ IL } \\
\hline $7 \mathrm{a}--8$ & 53.7 & 11.6 & 53.7 & 11.6 & 38.0 & 0.0 \\
$8--9$ & 59.8 & 11.6 & 42.0 & 0.0 & 59.8 & 11.6 \\
$9--10$ & 53.7 & 11.6 & 53.7 & 11.6 & 38.0 & 0.0 \\
$10--11$ & 53.7 & 11.6 & 38.0 & 0.0 & 53.7 & 11.6 \\
$11--12$ & 59.8 & 11.6 & 59.8 & 11.6 & 42.0 & 0.0 \\
$12--13$ & 53.7 & 11.6 & 38.0 & 0.0 & 53.7 & 11.6 \\
\hline
\end{tabular}

Moment and shear force analysis envelopes is shown in the Figure 5.
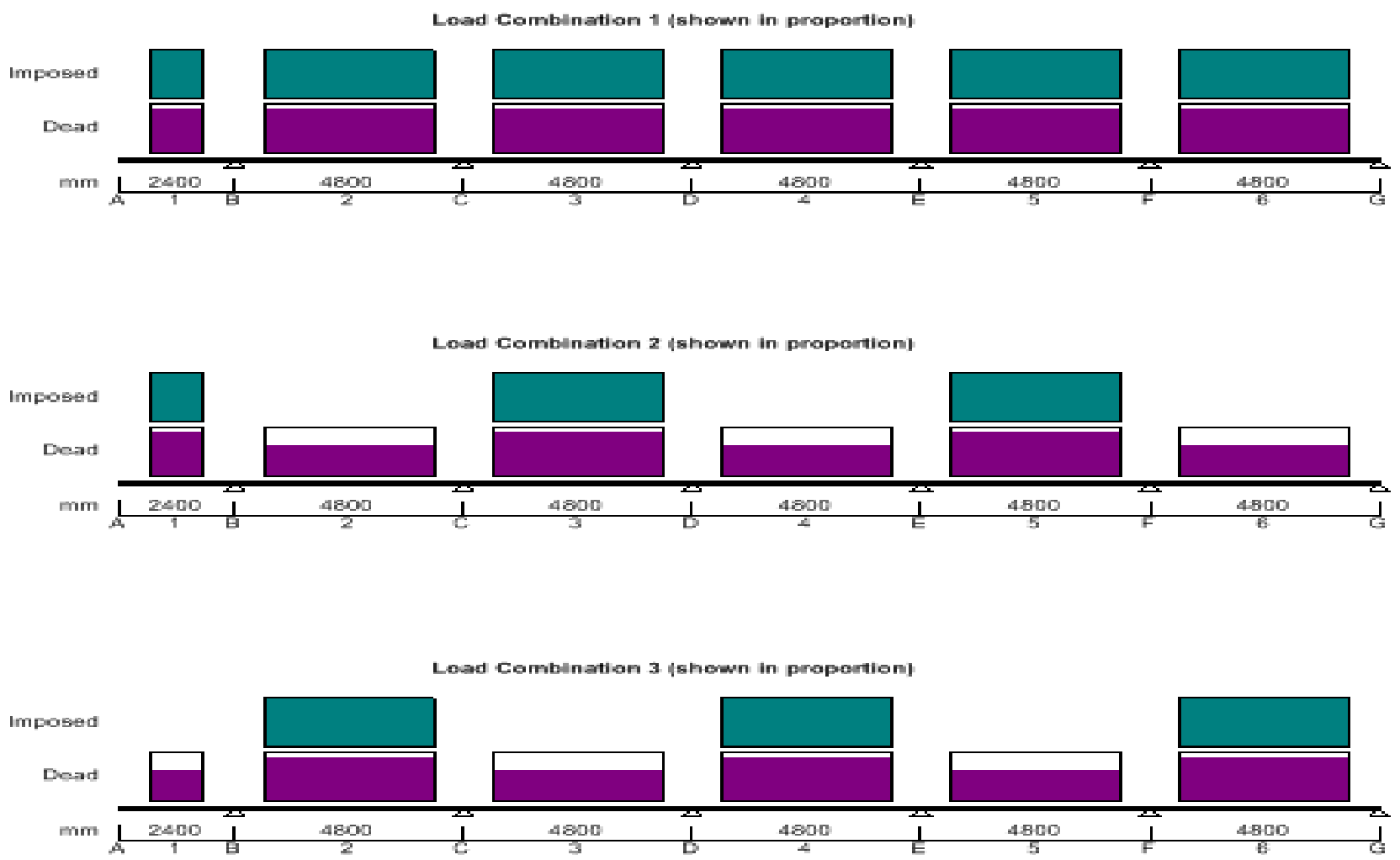

Fig 5: Load Combinations (BS 8110)

Table 3: Beam 2B Load Case (Eurocode 2)

\begin{tabular}{|c|c|c|c|c|c|c|c|c|c|c|c|c|}
\hline \multirow{2}{*}{ SPAN } & \multicolumn{2}{|c|}{ CASE 1} & \multicolumn{2}{|c|}{ CASE 2} & \multicolumn{2}{|c|}{ CASE 3} & \multicolumn{2}{|c|}{ CASE 4} & \multicolumn{2}{|c|}{ CASE 5} & \multicolumn{2}{|c|}{ CASE 6} \\
\hline & DL & IL & DL & IL & DL & IL & DL & IL & DL & IL & $\mathrm{DL}$ & IL \\
\hline $7 a--8$ & 53.7 & 11.6 & 53.7 & 11.6 & 38.0 & 0.0 & 38.0 & 0.0 & 38.0 & 0.0 & 38.0 & 0.0 \\
\hline 8 -- 9 & 59.8 & 11.6 & 42.0 & 0.0 & 59.8 & 11.6 & 59.8 & 11.6 & 59.8 & 11.6 & 59.8 & 11.6 \\
\hline $9-10$ & 53.7 & 11.6 & 53.7 & 11.6 & 38.0 & 0.0 & 38.0 & 0.0 & 38.0 & 0.0 & 38.0 & 0.0 \\
\hline $10-11$ & 53.7 & 11.6 & 38.0 & 0.0 & 53.7 & 11.6 & 53.7 & 11.6 & 53.7 & 11.6 & 53.7 & 11.6 \\
\hline $11-12$ & 59.8 & 11.6 & 59.8 & 11.6 & 42.0 & 0.0 & 42.0 & 0.0 & 42.0 & 0.0 & 42.0 & 0.0 \\
\hline $12-13$ & 53.7 & 11.6 & 38.0 & 0.0 & 53.7 & 11.6 & 53.7 & 11.6 & 53.7 & 11.6 & 53.7 & 11.6 \\
\hline
\end{tabular}



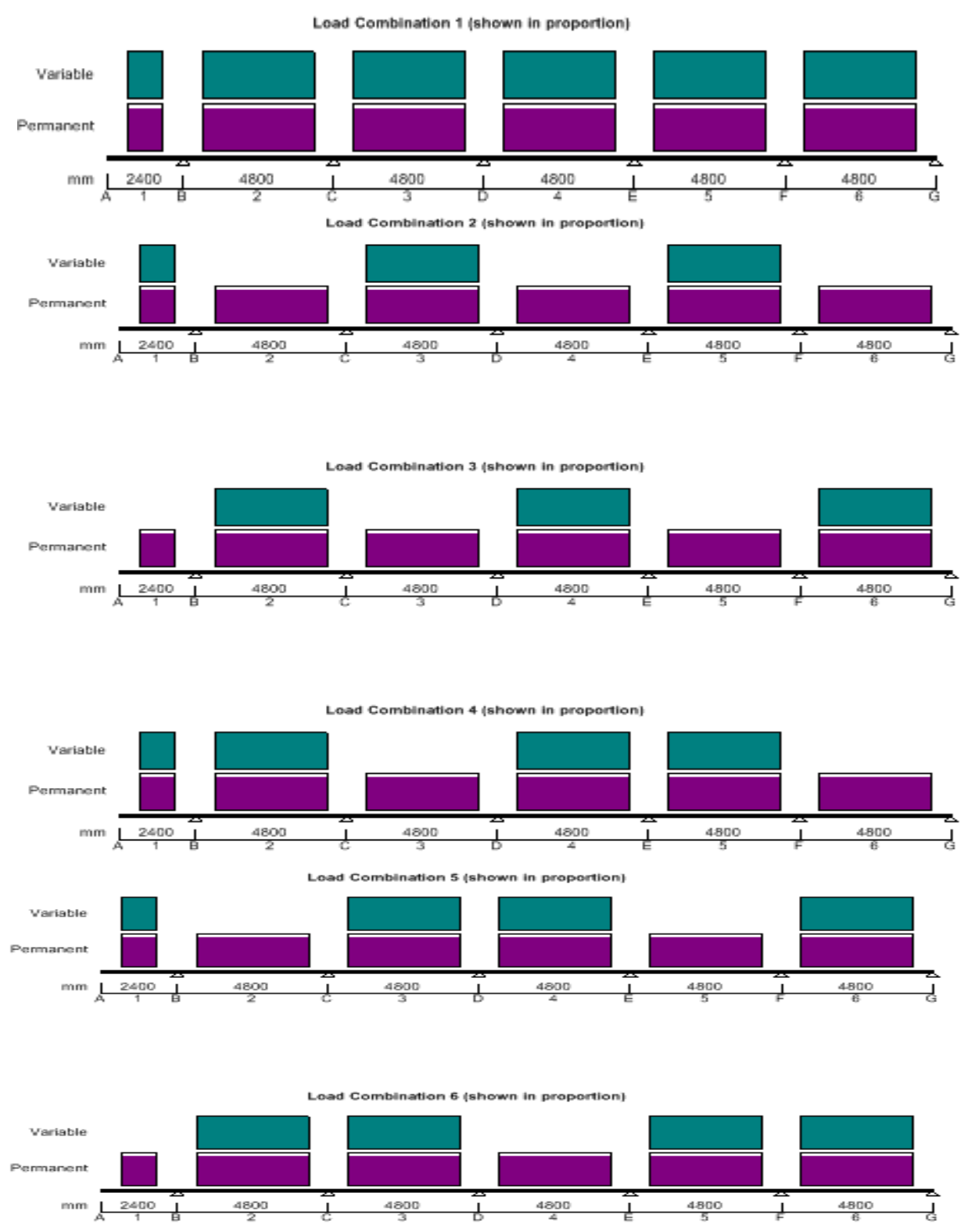

Fig 6: Load Combinations (Eurocode 2)
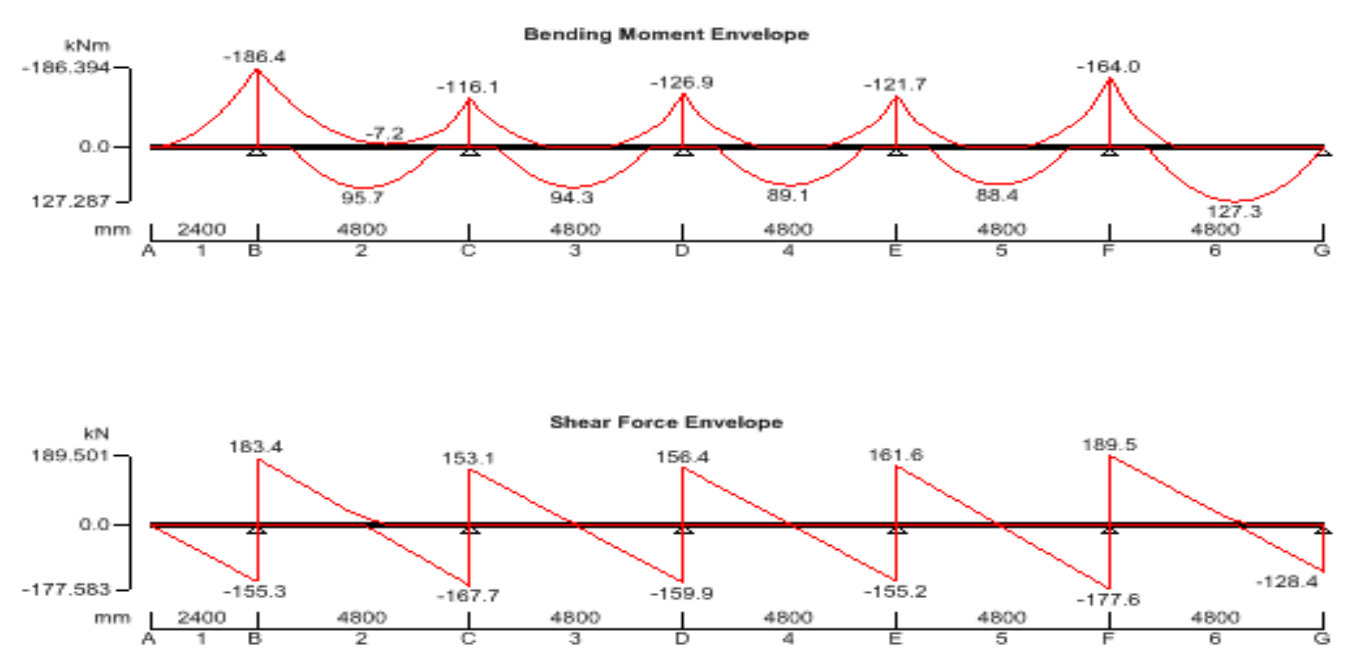

Fig 7: Bending Moment and Shear Force Envelop (BS 8110) 

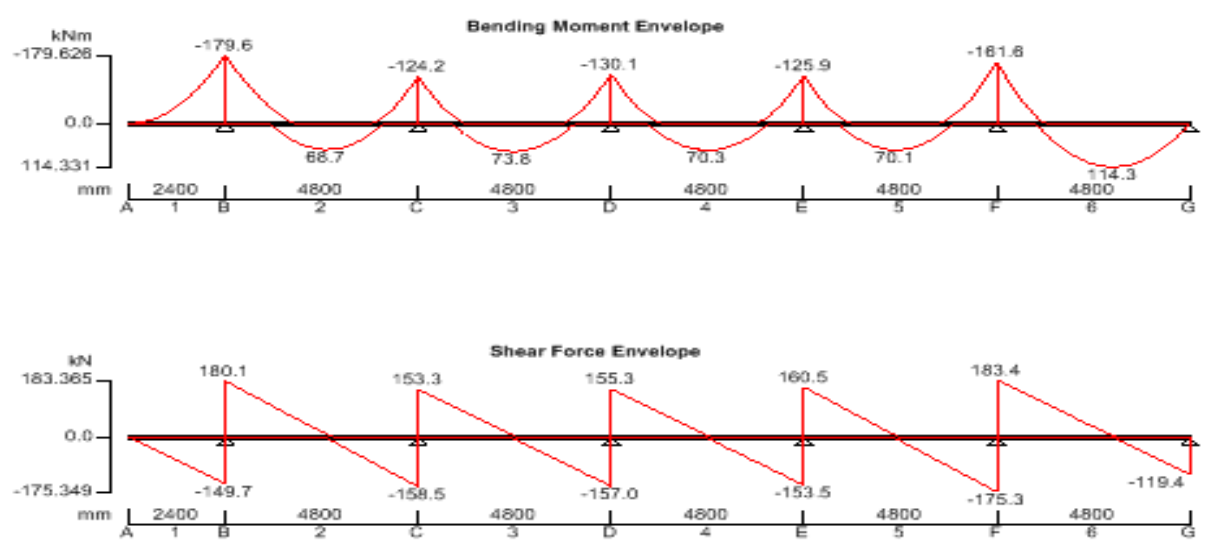

Fig 8: Bending Moment and Shear Force Envelop (Eurocode 2)

\subsection{Column Loading and Analysis}

Column analysis loading and analysis for column $\mathrm{C} 1$ is summarized in Table 4.

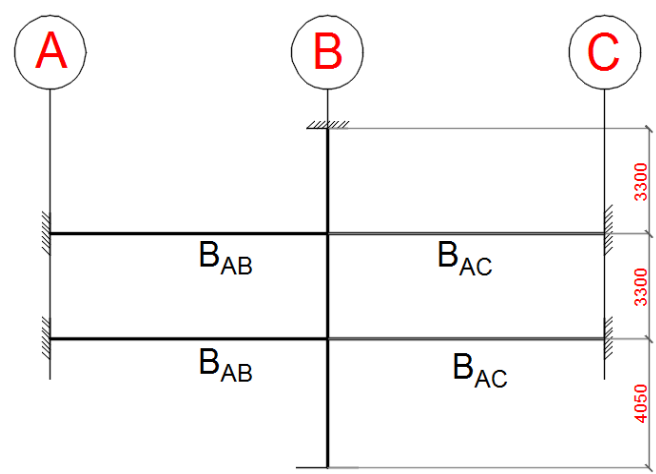

Fig. 7: Sub frame sketch for Column C1

Table 4: Column axial load and bending moments for BS 8110 and $E C 2$

\begin{tabular}{|l|l|c|c|c|}
\hline \multirow{2}{*}{ LEVEL } & & BS 8110 & EC 2 & $\%$ diff \\
\hline \multirow{2}{*}{ 2ND FLOOR Under side } & $\mathrm{M}(\mathrm{KNm})$ & 790 & 577 & -36.92 \\
\cline { 2 - 5 } & $\mathrm{N}(\mathrm{KN})$ & 1565 & 1335 & -17.22 \\
\hline \multirow{2}{*}{ FIRST FLOOR Under side } & $\mathrm{M}(\mathrm{KNm})$ & 0 & 0 & 0 \\
\cline { 2 - 5 } & $\mathrm{N}(\mathrm{KN})$ & 2294 & 2174 & -5.52 \\
\hline
\end{tabular}

\subsection{Foundation loading and analysis}

Foundation load from column analysis loading and analysis for Base type 1 is summarized in Table 5.

Table 5: Foundation load for BS 8110

\begin{tabular}{lccc}
\hline & $\mathrm{G}_{\mathrm{k}}(\mathrm{kN})$ & $\mathrm{Q}_{\mathrm{k}}(\mathrm{kN})$ & Total $(\mathrm{kN})$ \\
\hline \multicolumn{4}{c}{$\mathrm{BS} 8110$} \\
Design Load & 1789 & 520 & 2309 \\
Service Load & 1277 & 325 & 1602 \\
\hline \multicolumn{4}{c}{$\mathrm{EC} 2$} \\
Design Load & 1770 & 489 & 2259 \\
Service Load & 1311 & 325 & 1684 \\
\hline
\end{tabular}

\section{RESULTS AND DISCUSSION}

From Figures 7 and 8, it is apparent that BS8110 tends to take moment dominance along the span. Eurocode 2 yields higher values of hogging moments at the supports. BS 8110 takes dominance in support shear forces too. This difference in trend is attributed to the different manner adopted by both codes to determine the design loads as well as the different approach taken in evaluating the worst load case for design (or pattern) loading. This can be readily appreciated from Table 2 and 3. The current trend of moment difference appears sensible due to the fact that BS8110 applies larger partial safety factors to loads (or actions in Eurocode 2) at the ultimate limit state in contrast to Eurocode 2. For the latter, both $\gamma G$ and $\gamma Q$ the partial safety factors with respect to dead and imposed loads respectively are marginally lower compared with the BS8110 values.

In the column design, the out of balance moment for Eurocode 2 lower is owing to the load case adopted in determining this moment. BS uses ultimate load on longer span and a service load of $1.0 \mathrm{Gk}$ on the shorter span while Eurocode 2 uses ultimate load on longer span and a service load of $1.35 \mathrm{Gk}$ on the shorter span. Therefore, the out of balance moment is consequently lower for Eurocode 2 because the load difference between the beam arms connected to the column is lesser.

For the footings, Table 5 and $\mathrm{b}$ shows that the estimated foundation service load for BS 8110 is lower than that of EC. This is due to the unit weight of $25 \mathrm{kN} / \mathrm{m}^{3}$ adopted by EC 2 against the $24 \mathrm{kN} / \mathrm{m}^{3}$ adopted by BS 8110 . This results in a larger pad area in design.

Similar studies have been carried out in the United Kingdom and these were instrumental in the development of the present investigation which focuses on loading and analysis (for illustrative purposes only), ease of use and technological advancement and economy. Highlights of the above study are:

(1) For the critical continuous beam section examined, the EC2 moments at internal supports generally exceed the BS8110 values by a range of $0 \%-8.5 \%$, at all levels of moment redistribution. 
(2) With respect to maximum span moments in the continuous beam, the EC2 moments are lower than the BS8110 values by about $4.5 \%-9 \%$, for moment redistributions up to $20 \%$. However at $30 \%$ redistribution the lag is about $14.3 \%$, but this is felt to be an isolated case.

(3) The manner in which the partial load safety factors are applied as well as the procedures adopted in arriving at the worst loading scenario for pattern loadings in respect of the two codes contributes significantly to the difference in moments observed at the critical locations in both Ecurocode 2 and BS8110.

(4) In the case of the upper and lower limits of the shear force envelopes, BS8110 estimates are generally higher by a range of $2.4 \%-5.4 \%$. However, some caution should be placed on these results for the trend is certainly not consistent [7].

Based on the analysis of results of the study carried out in section 4, the following comparisons were made;

\subsection{Ease of Use and Time savings}

In the analysis of beams, the load cases adopted by the Eurocode 2 for the determination of shear force and moment envelops shows that it is more than that of BS 8110 and so shows that Eurocode 2 does not save time. However, there are softwares that can carry out the analysis easily so this eliminates the problem. A critical look at the two codes suggests that Eurocode 2 is more flexible to use. The ease may be strongly dependent to usage and experience. It may not save time at the present acclimatization phase but it will in the future if it is adopted and if engineers get accustomed to it.

\subsection{Technological Advancement}

Research is continuous and technological breakthroughs are talks everywhere in the science fare. This is why text books and codes are revised/updated. According to Building.co.uk [8], the structural Eurocodes have finally replaced British standard and the British standards will not be updated again and that all research efforts are now directed to improving the Eurocodes. Therefore, the EC2 is technologically more advanced that the BS 8110 and will be the code that will continue to enjoy this advancement [9].

\section{CONCLUSION}

The structural design of most buildings worldwide is based on national and/or international codes of practice. These guide the engineer in the appraisal of the overall structural scheme, detailed analysis and design. Codes of practice are basically aids drawn up by experienced engineers and allied professionals, and they provide a framework for addressing issues of safety and serviceability in structural design. A comparative study of the analysis and design provisions in respect of various structural elements was performed. The emphasis here however, has almost exclusively been on beams. Based on the results of the study, the following conclusions have been reached:

1. With respect to maximum span moments, the Eurocode 2 moments are lower than the BS8110 values while for support moments in the continuous beam, the Eurocode 2 moments supersede the BS8110 moments.

2. The manner in which the partial load safety factors are applied as well as the procedures adopted in arriving at the worst loading scenario for pattern loadings in respect of the two codes contributes significantly to the difference in moments observed at the critical locations in both EC2 and BS8110.

3. In the case of the upper and lower limits of the shear force envelopes, BS8110 estimates are generally higher (with up to 3 to $10 \%$ ). However, some caution should be placed on these results for the trend is certainly not consistent.

4. With respect to column load and moments, the EC2 values are lower than the BS8110 values.

5. With respect to foundation load (service), the EC2 moments are higher than the BS8110 values and hence larger pad areas while for ultimate load, the EC2 moments are lower than the BS8110 values.

6. The Eurocode as used in reinforced concrete design is more technologically advanced and will continue to enjoy more advancement. It is more flexible and safer and more economical given the number of load conditions taken to get the moment and shear force envelops.

7. From the design for both BS $8110-97$ and EC2 and result discussion in the foregoing chapters, we can draw the conclusion that Eurocode 2 is easier to use, will provide more economical section (based on observed lesser moments) and is technologically more advanced than BS 8110 .

\section{REFERENCES}

[1] Morgan, W., J. F. Claydon "Reinforced Concrete". Pdf. In The Elements of Structure. www.pssurvival.com/PS/CementConcrete/Reinforced_Concrete-2016.pdf, Assessed 25 April, 2016.

[2] Wikipedia, "Reinforced_concrete" http://en. wikipedia.com/Reinforced concrete, Assessed on 25 April, 2016.

[3] Wikipedia, "Steel" https://en.wikipedia.org/wiki/ Steel, Assessed on 25 April, 2016. 
[4] Yakut A. "Reinforced Concrete Frame Construction", http://www.world-housing.net/wp content/uploads/2011/06/RC-Frame_Yakut.pdf, Assessed on 23 February, 2017.

[5]British Standards Institution. BS 8110-1: Structural use of concrete. BSI, 1997.

[6]www.concretecentre.com/codes standards/eurocode s/eurocode 2.aspx, Assessed on 30 March, 2016.

[7] Shodolapo O. F.,\& Kenneth K. M. "A Comparative Study of EC2 and BS8110 Beam Analysis and Design in a Reinforced Concrete Four Storey Building", www.textroad.com/pdf/JBASR/J.\%20Basic.\%20Appl. \%20Sci.\%20Res.,\%201(12)3172-3181,\%202011.pdf, Assessed 25 February, 2015.

[8]BRITISH STANDARDS INSTITUTION. BS EN 1992-1, Eurocode 2: Design of concrete strucutures - General rules. , London, BSI, 2004.
[9] Mosley, et al. Reinforced Concrete Design". Sixth Edition, New York, Palgrave Macmillan, 2007.

[10]Reynolds, C.E., J.C. Steedman and A.J. Threlfall. Reynolds's Reinforced Concrete Designer's Handbook, 11th Edition., London, Taylor and Francis, 2008.

[11]Lane T. "Eurocode Replaces British Standards", http://www.building.co.uk/eurocodes-replacebritish-standards/3161244.article, Assessed 25 April, 2016.

[12]Gulvanessian H. , “The Eurocodes become Britain's new standards for structural design", 284 http://shop.bsigroup.com/upload/Standards $\% 20 \& \%$ 20Publications/Eurocodes/cien163009\%20gulvanessian.pdf, Assessed 19 June, 2016. 